\title{
PENGARUH KEPEMIMPINAN KEPALA SEKOLAH, MOTIVASI KERJA, DAN BUDAYA ORGANISASI TERHADAP KOMPETENSI GURU SMA
}

\author{
Muhammad Junaidi Syakir, Pardjono \\ SMA N 5 Yogyakarta, Universitas Negeri Yogyakarta \\ junsyakir@yahoo.co.id, pardjono@uny.ac.id
}

\begin{abstract}
Abstrak
Penelitian ini bertujuan untuk mengetahui pengaruh kepemimpinan kepala sekolah, motivasi kerja dan budaya organisasi, baik secara bersama-sama atau sendiri-sendiri, terhadap kompetensi guru (variabel terikat) menurut persepsi guru SMA Negeri kota Yogyakarta. Hasil penelitian berdasarkan analisis regresi linier ganda menunjukkan bahwa kepemimpinan kepala sekolah, motivasi guru, dan budaya organisasi secara bersama-sama berpengaruh secara signifikan dan positif terhadap kompetensi guru dengan hasil $\mathrm{R}(1,2,3)=$ 0,342; F =4,448; df: 3: $101=2,694$, sig 0,006 < 0,05; sehingga F hitung > F tabel dan Sig. F < 5 $\%$. Namun demikian hasil uji t menunjukkan kepemimpinan kepala sekolah secara parsial tidak berpengaruh positif dan signifikan terhadap kompetensi guru, hasil uji $\mathrm{t}$ juga menunjukkan bahwa motivasi kerja tidak berpengaruh positif dan signifikan terhadap kompetensi guru, secara parsial hanya budaya organisasi yang menunjukkan pengaruh positif dan signifikan terhadap kompetensi guru.
\end{abstract}

Kata kunci: kepemimpinan kepala sekolah, motivasi kerja, budaya organisasi, dan kompetensi guru

\section{THE INFLUENCE OF HEADMASTER LEADERSHIP, WORK MOTIVATION, AND ORGANIZATIONAL CULTURE ON TEACHER'S COMPETENCY OF HIGH SCHOOL}

\author{
Muhammad Junaidi Syakir, Pardjono \\ SMA N 5 Yogyakarta, Universitas Negeri Yogyakarta \\ junsyakir@yahoo.co.id,pardjono@uny.ac.id
}

\begin{abstract}
This research is aimed to know the influence of headmaster leadership, work motivation, and organizational culture on teacher's competency according to teachers at State Senior High Schools in Yogyakarta city simultaneously or individually of independent variable to dependent variable. The linearity analysis of multivariate regression shows that the headmaster leadership, work motivation, and organizational culture simultaneously influence the teachers'competency positively and significantly with the value of $R(1,2,3)=$ 0.342; F $=4.448$; df: 3: $101=2.694 ;$ sig $0.006<0.05$; so F $>$ F table and sig. F $<5 \%$. The analysis with test $\mathrm{t}$ shows that the headmaster leadership partially does not influence on teachers'competency significantly and positively; work motivation partially does not influence on teachers'competency significantly and positively; but organizational culture partially influences on teachers' competency significantly and positively.

Keywords: leadership of the headmaster, work motivation, organizational culture, and teacher's competency
\end{abstract}





\section{Pendahuluan}

Pendidikan merupakan wahana untuk meningkatkan sumber daya manusia Indonesia. Melalui pendidikan diharapkan semua kemampuan peserta didik berkembang, baik potensi ketaqwaan, kecerdasan, kecakapan, kemandirian, dan potensi-potensi lain yang dimiliki.

Untuk dapat menyelenggarkan pendidikan yang dapat memenuhi kriteria tersebut di atas, maka diperlukan kesiapan sumber daya manusia yang terlibat di dalamnya, terutama dalam proses pendidikan. Diantara faktor penentu keberhasilan dalam dunia pendidikan, faktor utama dan ujung tombak peningkatan mutu pendidikan adalah guru.

Guru memiliki posisi yang sangat strategis dalam menyiapkan masa depan bangsa melalui keberhasilannya dalam membekali anak-anak didiknya dengan ilmu pengetahuan yang memadai, membentuk karakter anak-anak yang berakhlaq mulia, memiliki etos belajar yang tinggi, dan kesiapan berkompetisi dengan bangsabangsa lain di dunia ini (Suyanto dan Hisyam, 2000, p.27).

Dari pernyataan ini tergambar betapa guru merupakan salah satu komponen mikrosistem pendidikan yang sangat strategis dan banyak mengambil peran di dalam proses pendidikan secara luas.

Mengingat peran guru yang sangat vital, maka guru perlu melakukan tugas dan fungsinya sebagai insan pendidik secara profesional, tidak asal-asalan. Guru perlu menunjukkan pekerjaannya sebagai sebuah pekerjaan yang digeluti dengan penuh pengabdian dan dedikasi serta dilandasi oleh keahlian atau keterampilan tertentu, sebagaimana tertuang dalam UU RI Nomor 14 tahun 2005 tentang Guru dan Dosen.

Kemampuan guru akan menjadi salah satu penentu keberhasilan pendidikan. Dengan kemampuannya, guru dapat mempengaruhi peserta didik untuk berkemauan belajar dengan sungguh-sungguh, juga mempengaruhi peserta didik untuk mengembangkan potensi yang dimilikinya sehingga anak memiliki sikap mandiri, sikap sosial, dan kemampuan akademik yang diperlukan untuk pengembangan pengetahuan selanjutnya. Wrightman mengatakan bahwa peranan guru adalah menciptakan serangkaian tingkah laku yang saling berkaitan yang dilakukan dalam suatu situasi tertentu serta berhubungan dengan kemajuan perubahan tingkah laku dan perkembangan siswa yang menjadi tujuannya (Usman, 2002, p.13). Mengingat peranan guru yang sangat penting, maka guru menjadi personal yang terlibat langsung dalam perencanaan, pelaksanaan, dan evaluasi pembelajaran yang dilakukan demi mencapai tujuan pendidikan. Peranan guru dalam proses pendidikan tak tergantikan. Guru bahkan menjadi tokoh utama bagi anak-anak didiknya untuk dicontoh dan diteladani.

Darling-Hammon, dan kawan-kawan (2006, p.4) mengungkapkan: "In a world where education matters more than it ever has before, parents and policymakers alike are asking how to find the extraordinary teachers who can help all children acquire the increasingly complex knowledge and skills they need". Ungkapan ini menunjukkan harapan yang tinggi dari masyarakat akan kesempurnaan kemampuan guru. Karena tuntutan ekonomi dan sosial bagi tumbuhnya pendidikan, maka berimbas pada harapan yang tinggi akan keterampilan dan pengetahuan guru.

Guru dituntut memiliki kompetensi yang mampu dan dapat merealisasikan harapan masyarakat karena mengemban harapan akan keberhasilan pendidikan. Kompetensi guru mempunyai spesifikasi atau kriteria tertentu. Kompetensi guru dapat dilihat dan diukur berdasarkan spesifikasi atau kriteria kompetensi yang harus dimiliki setiap guru. Berdasarkan Peraturan Menteri Pendidikan Nasional Republik Indonesia Nomor 16 tahun 2007 tentang Standar Kualifikasi Akademik dan Kompetensi Guru, dijelaskan bahwa standar kompetensi guru dikembangkan secara utuh dari 4 kompetensi utama, yaitu: (1) kompetensi pedagogik, (2) kepribadian, (3) sosial, dan (4) profesional. Keempat kompetensi tersebut terintegrasi dalam kinerja guru. 
Idealisme kompetensi guru yang mencakup ke empat kompetensi tersebut seharusnya tercermin dalam pelaksanaan tugas guru dalam kegiatan sehari-hari. Cerminan keempat kompetensi tersebut terealisasi dalam tugas keguruannya di dalam kelas dan tugas kependidikannya di luar kelas, diantaranya adanya rasa tanggung jawab dalam mempersiapkan segala perlengkapan pengajaran sebelum melaksanakan proses pembelajaran, mempertimbangkan metodologi yang akan digunakan, alat-alat media pembelajaran yang akan digunakan, alat dan bentuk evaluasi pembelajaran yang akan dilakukan, dan sebagainya. Merealisasikan kompetensi yang dimiliki guru semacam ini yang akan mempengaruhi mutu pendidikan kita.

Hasil kerja guru berdasarkan pengembangan kompetensi yang dimiliki salah satunya dapat dilihat dari hasil prestasi siswa yang diperoleh karena berkaitan dengan tahap penilaian seberapa jauh ketercapaian tujuan pembelajaran (Soetjipto dan Kosasi, 1999, p.138). Nilai Ujian Nasional tahun 2012 dari SMA Negeri sekota Yogyakarta yang termuat di KR pada tanggal 19 Juni 2012 memperlihatkan rata-rata nilai Ujian Nasional yang sangat variatif antara SMA negeri satu dengan SMA negeri yang lainnya. Hal ini bisa ditafsirkan bahwa kompetensi guru antara sekolah yang satu dengan sekolah yang lainnya berbeda.

Berdasarkan informasi yang diperoleh di lapangan, pra-survey, diperoleh gambaran bahwa hampir seluruh guruguru SMA negeri kota Yogyakarta telah mengikuti sertifikasi guru dan memiliki sertifikat pendidik dan sekaligus mendapatkan uang tunjangan sertifikasi guru. Dengan adanya sertifikasi diharapkan guru berusaha meningkatkan kompetensi yang seharusnya dimiliki. Namun demikian berdasarkan pendapat Menteri Pendidikan dan Kebudayaan sendiri yaitu Mohammad Nuh yang termuat di harian Kompas tanggal 1 November 2010 dan 31 Oktober 2011 dikatakan bahwa guru yang sudah lulus sertifikasi umumnya belum menunjukkan kemajuan dalam hal penguasaan kompetensi yang seharusnya dimiliki, baik dari segi kompetensi pedagogis, kompetensi kepribadian, kompetensi profesional, maupun kompetensi sosial.

Kompetensi guru sangat dipengaruhi oleh banyak faktor. Faktor pertama adalah faktor kepemimpinan kepala sekolah. Dalam sistem penyelenggaraan pendidikan di tingkat persekolahan, kepala sekolah memiliki peran yang sangat strategis di dalam memberdayakan guru-gurunya dalam meningkatkan mutu pendidikan. Sallis mengatakan bahwa aspek penting dari kepemimpinan dalam pendidikan adalah bagaimana memberdayakan para guru dan memberi mereka wewenang yang luas untuk meningkatkan pembelajaran para pelajar (2008, p.174). Sebagai pemimpin, kepala sekolah harus menjalankan perannya dengan baik. Terry dalam Hersey dan Blanchard mengatakan bahwa, "leadership is the activity of influencing people to strive willingly for group objectives", kepemimpinan adalah kegiatan untuk mempengaruhi orang (bawahannya) demi berjuang keras menggapai tujuan-tujuan kelompok, dalam hal ini adalah keberhasilan tujuan-tujuan pendidikan (1982, p.82). Disamping sebagai pemimpin, kepala sekolah juga seorang manajer. Sebagai manajer, kepala sekolah harus mampu merencanakan, mengorganisasi, melaksanakan, memimpin dan mengendalikan usaha para anggota organisasi serta memberdayakan seluruh sumber daya-sumberdaya organisasi dalam rangka mencapai tujuan yang telah ditetapkan (Mulyasa, 2005, p.103). Ini berarti kepala sekolah harus mau dan mampu mendayagunakan seluruh sumberdaya sekolah terutama para guru dalam rangka mewujudkan visi, misi dalam rangka mencapai tujuan pendidikan di sekolahnya. Diantara modal untuk mencapai tujuan pendidikan itu adalah penguasaan kompetensi guru yang memadai.

Harapan akan peranan kepala sekolah seperti kriteria yang telah dipaparkan di atas pada kenyataannya tidak sepenuhnya dapat terwujud secara maksimal. Fungsi kepala sekolah sebagai pemimpin maupun sebagai manajer masih belum sepenuhnya dapat diharapkan. Masih banyak 
kepala sekolah yang tidak menjalankan tugas dan fungsinya sebagai pemimpin pendidikan yang diharapkan (Mania, 2011, p.53). Sebagai educator, kepala sekolah belum mampu meningkatkan profesionalitas para guru. Kepala sekolah juga dipandang belum mampu merencanakan dan memimpin realisasi peningkatan mutu pengajaran. Dalam hal pelaksanaan kurikulum dan administrasi keuangan, (1) kepala sekolah masih harus meningkatkan kemampuan tata kelolanya, (2) berkaitan dengan mutu pengajaran masih banyak ditemui kepala sekolah yang tidak melaksanakan supervisi terhadap guru, atau bila dapat melaksanakan supervisi, kepala sekolah belum memberikan supervisi pada substansi kegiatan supervisi, (3) kepala sekolah juga belum mampu memberikan motivasi para guru untuk selalu kreatif dan produktif. Karya-karya guru di bidang kreativitas pembelajaran masih rendah. (4) Karena sistem rekruitmen kepala sekolah yang belum tepat, masih banyak ditemui kepala sekolah sebetulnya tidak memiliki keahlian untuk memimpin sekolah, walaupun sebagai guru dia sangat baik.

Selain faktor kepemimpinan kepala sekolah, faktor lain yang mempengaruhi kinerja guru adalah motivasi kerja guru. Martoyo mengatakan motivasi kerja adalah sesuatu yang menimbulkan dorongan atau semangat kerja atau dengan kata lain pendorong semangat kerja (Farlen, 2011). Para pekerja, termasuk guru di dalamnya, dalam organisasi apapun memerlukan sesuatu yang tetap membuat mereka mau terus bekerja. Keinginan untuk mau melakukan sesuatu atau berbuat, dalam hal ini terus bekerja, ini dinamai dengan motivasi (Hersey dan Blanchard, 1982, p.15). Tanpa adanya motivasi kerja, seseorang pekerja termasuk guru, tidak akan bekerja dengan baik sehingga hasil pekerjaannya tidak akan memuaskan.

Motivasi kerja sangat dipengaruhi oleh tingkat kebutuhan seseorang. Bila tingkat kebutuhan akan sesuatu sangat kuat pada seseorang, maka ia akan bersaha memenuhi kebutuhan itu dari kebutuhan yang lain yang tidak mendesak, atau dari kebutuhan yang sudah terpenuhi. Hersey dan Blanchard berpendapat, "we have argued that the behavior of individuals at a particular moment is usually determined by their strongest need" (1982, p.26). Tingkat kebutuhan yang berbeda ini akan mempengaruhi motivasi seseorang dalam unjuk kerjanya. Dengan demikian dimungkinkan bahwa motivasi kerja guru di sma negeri kota Yogyakarta sangat bervariatif. Mulai dari motivasi kerja karena adanya imbalan yang bersifat materi atas kerja yang ia lakukan, sampai motivasi kerja karena sesuatu yang sifatnya immateri.

Salah satu yang dimungkinkan mempengaruhi motivasi kerja guru adalah adanya ketentuan guru harus memenuhi jumlah jam mengajar sebanyak 24 jam/minggu. Guru yang sudah dapat memenuhi jumlah minimal jam mengajar, memperoleh uang sertifikasi guru yang besarnya sebesar 1 kali gaji. Dengan memperoleh tambahan uang sertifikasi yang jumlahnya tidak sedikit, meningkatkan motivasi kerja guru untuk bekerja lebih baik. Sementara bagi mereka yang tidak dapat memenuhi jumlah jam minimal tidak memperoleh uang sertifikasi. Tidak adanya tambahan gaji ini sedikit banyak akan mempengaruhi motivasi para guru. Ada juga guru yang berusaha memenuhi jumlah jam dengan mengajar di sekolah negeri yang lain sehingga motivasi mengajarnya lebih kepada untuk memenuhi jumlah jam mengajar agar memperoleh tambahan gaji berupa uang sertifikasi. Motivasi kerja guru semacam ini tentu orientasinya lebih banyak kepada adanya tambahan gaji, bukan pada peningkatan kinerja agar kualitas hasil pendidikan lebih baik. Oleh karena itu tidak salah apabila kondisi sosial-ekonomi dan beban tugas serta rutinitas pekerjaan mempengaruhi motivasi kompetensi guru (Hendri, 2010).

Selain motivasi yang muncul dari diri seseorang, Robbin mengemukakan bahwa motivasi juga timbul karena keinginan untuk melakukan sesuatu sebagai kesediaan untuk mengeluarkan tingkat upaya yang tinggi untuk tujuan-tujuan organisasi, yang dikondisikan oleh kemampuan upaya itu 
untuk memenuhi suatu kebutuhan individual (Brahmasari dan Suprayetno, 2008, p.125). Kemampuan kepala sekolah menjadikan kebutuhan individual selaras dengan kebutuhan atau tujuan organisasi akan meningkatkan daya gerak guru memaksimalkan potensi yang dimiliki.

Faktor lain yang mempengaruhi kinerja guru adalah budaya kerja sekolah atau budaya organisasi di sekolah itu. Budaya organisasi mempengaruhi sikap dan perilaku anggota organisasi (Robbins, 1996, p.288). Oleh karena itu budaya organisasi yang berkembang sedemikian rupa menghasilkan perilaku-perilaku tertentu dari para pelaku pendidikan di sekolah. Budaya organisasi memiliki sejumlah tradisi, kebiasaan, nilai, aturan main, dan simbol-simbol sekolah yang membuat sekolah itu berbeda dari sekolah yang lain. Robbins juga menyatakan bahwa ada kesepakatan yang luas bahwa budaya organisasi mengacu ke suatu sistem makna bersama yang dianut oleh anggota-anggota yang membedakan organisasi itu dengan organisasi-organisasi yang lain (1996, p.289). Sistem makna bersama ini, bila diamati lebih seksama, merupakan seperangkat karakteristik utama yang dihargai oleh organisasi itu. Salah satu karakterisitik itu adalah inovasi dan pengambilan resiko. Selanjutnya Robbin berpendapat sekolah (organisasi) yang memiliki budaya unggul adalah sekolah yang memberi peluang bagi anggota sekolah untuk melakukan inovasi dan pengambilan resiko. Sekolah memberikan dorongan bagi anggota organisasi sekolah untuk melakukan inovasi dan kreatifitas, walaupun inovasi-inovasi tadi memiliki resiko kegagalan, akan tetapi demi visi sekolah ke depan, sekolah memberikan peluang untuk mencoba, dan kegagalan merupakan bagian dari proses pembelajaran.

Tuntutan budaya organisasi agar muncul kebiasaan untuk melakukan kegiatan yang inovatif dan kreatif seperti yang disebutkan Robbin di atas masih belum menjadi budaya di kalangan guru. Sebagai contoh adalah apa yang dikemukakan Mustofa di harian Radar Lampung, menurutnya masih banyak guru yang tidak biasa melakukan pembelajaran secara kreatif, tetapi cenderung mengelola kelas secara konvensional sebagaimana mereka dulu diajar oleh gurunya (Radar Lampung, Kamis - 22 November 2012).

Masih berkaitan dengan budaya oganisasi, Preedy berpendapat: "Organizational culture is the characteristic spirit and belief of an organization, demonstrated, for example, in the norms and values that are generally held about how people should treat each other, the nature of working relationships that should be developed and attitudes to change. These norms are deep, taken-for-granted asssumptions that are not always expressed, and are often known without being understood" (1993, p.45).

Budaya organisasi adalah keyakinan dan semangat khas suatu organisasi yang dinampakkan, contohnya dalam nilai-nilai dan norma yang pada umumnya dipedomani tentang bagaimana orang harus bertindak satu dengan yang lainnya, hubungan kerjasama yang semestinya dikembangkan dan sikap-sikap untuk melakukan perubahan. Norma-norma ini adalah asumsiasumsi yang diyakini secara mendalam yang tidak dapat diungkapkan dan diketahui, kecuali dengan cara dipahaminya.

Dapat disimpulkan bahwa budaya kerja atau budaya organisasi adalah wujud perilaku yang dinampakkan oleh suatu masyarakat atau organisasi sebagai manifestasi atau cermin dari nilai-nilai dan norma yang diyakininya dan dijadikan pedoman, dan harapan-harapan yang ingin digapai. Cerminan langsungnya dapat berupa cara bersikap dan bertindak para pemimpin dan bawahannya, bagaimana mereka memilih cara dalam menangani persoalan, dan cara berfikir dan berperilaku mereka, termasuk bagaimana cara mereka bekerja sama.

Harapan terciptanya budaya organisasi yang mampu menumbuhkan kreatifitas dan peran guru atau anggota organisasi sekolah kadang tidak seperti yang diharapkan. Salah satunya adalah masih kurangnya peran guru dalam turut menentukan kebijakan sekolah (Tri Kurniah, 2011). Cotton, pada koleksi tulisan Zamroni tentang BSM, dalam temuannya tentang penerapan 
manajemen di sekolah mengatakan bahwa "Teachers have often been isolated from involvement in significant decision making and from frequent and meaningful contact with one another" (Zamroni, 2008, p.45). Guru sering tidak banyak dilibatkan dalam pengambilan keputusan yang berkaitan dengan tugas profesi dan dalam melakukan koordinasi antara satu dengan yang lainnya. Sehingga budaya organisasi sekolah belum mampu menumbuhkan inovasi guru dalam berkarya demi kesuksesan pencapaian tujuan pendidikan, terutama di sekolahnya.

Berdasarkan paparan di atas, maka dapat diidentifikasi masalah-masalah sebagai berikut: (1) Guru yang sudah lulus sertifikasi umumnya belum menunjukkan kemajuan dalam peningkatan kompetensi profesi, baik dari segi pedagogis, kepribadian, profesional, maupun sosial, (2) Fungsi kepala sekolah sebagai pemimpin maupun sebagai manajer masih belum sepenuhnya dapat diharapkan. (3) Motivasi guru dalam bekerja sangat bervariatif yang tidak semuanya selaras dengan tujuan organisasi sekolah, (4) Budaya organisasi sekolah belum sampai pada tahap mampu menumbuhkan inovasi guru dalam berkarya demi kesuksesan pencapaian tujuan pendidikan, terutama di sekolahnya.

Banyak faktor yang mempengaruhi kompetensi guru di sekolah. Dalam tesis ini penulis hanya membatasi masalah pada skup kecil yaitu mengenai kompetensi guru yang ada di sekolah tepatnya di SMA negeri di kota Yogyakarta. Penulis membatasi masalah pada kompetensi guru SMA dan faktor-faktor yang mempengaruhi yaitu kepemimpinan kepala sekolah, motivasi kerja dan budaya organisasi menurut persepsi guru.

Berdasarkan pembatasan masalah, maka masalah dalam penelitian ini dirumuskan dalam dua masalah yaitu Masalah Mayor dan Masalah Minor. Masalah Mayor mencakup: (1) adakah pengaruh positif dan signifikan kepemimpinan kepala sekolah (2) motivasi kerja dan budaya organisasi secara bersama-sama terhadap kompetensi guru menurut persepsi guru SMA Negeri kota Yogyakarta.
Selanjutnya, Masalah Minor mencakup: (1) adakah pengaruh positif dan signifikan kepemimpinan kepala sekolah terhadap kompetensi guru menurut persepsi guru SMA Negeri di kota Yogyakarta, (2) adakah pengaruh positif dan signifikan motivasi kerja terhadap kompetensi guru, (3) adakah pengaruh positif dan signifikan budaya organisasi terhadap kompetensi guru.

Tujuan penelitian ini adalah untuk: (1) mengetahui secara bersama-sama pengaruh kepemimpinan kepala sekolah, motivasi kerja dan budaya organisasi terhadap kompetensi guru SMA Negeri di kota Yogyakarta menurut persepsi guru, (2) mengetahui pengaruh kepemimpinan kepala sekolah terhadap kompetensi guru, (3) mengetahui pengaruh motivasi kerja terhadap kompetensi guru, (4) mengetahui pengaruh budaya organisasi terhadap kompetensi guru.

Peneliti berharap hasil penelitian ini berguna baik secara teoritis maupun praktis, yaitu: (1) dapat menyumbangkan pengembangan keilmuan untuk peneliti selanjutnya, terutama yang berkaitan dengan: kepemimpinan kepala sekolah, motivasi kerja guru, pengembangan budaya organisasi sekolah; dan peningkatan kompetensi guru; (2) dapat dijadikan bahan peningkatan dalam hal : terjalinnya hubungan yang baik antara kepala sekolah dengan guru, dan sebaliknya, antara guru dan kepala sekolah, kepala sekolah dalam kepemimpinannya tidak mengedepankan hubungan atasan dan bawahan, demikian pula guru dapat memandang kepala sekolah sebagai figur pemimpin yang perlu dihormati dan didukung kebijakannya kearah tujuan pendidikan yang diharapkan, kepala sekolah dapat memberikan motivasi kerja guru dengan pengaruh jabatannya, kepala sekolah dan guru dapat membangun budaya organisasi yang menumbuhkan perilaku positif, tumbuhnya kesadaran guru untuk terus meningkatkan kompetensi guru melalui peningkatan kompetensi pedagogik, kepribadian, sosial, dan profesional, (3) hasil penelitian dapat dipakai sebagai dasar pertimbangan oleh pihak-pihak pengambil 
kebijakan di bidang pendidikan dalam rangka peningkatan kompetensi guru.

\section{Metode Penelitian}

Jenis, Waktu, Tempat dan Subjek Penelitian

Penelitian ini menggunakan pendekatan kuantitatif, desain penelitian yang digunakan adalah ex post facto, dengan maksud untuk melihat ada tidaknya pengaruh antara ketiga variabel bebas (kepemimpinan kepala sekolah, motivasi kerja, dan budaya organisasi) dengan variabel terikat (kompetensi guru).

Penelitian ini dilaksanakan pada bulan Mei dan Juni tahun 2013. Penelitian di selenggarakan di SMA negeri kota Yogyakarta, propinsi Daerah Istimewa Yogyakarta (DIY), dimana terdapat 11 sekolah di kota Yogyakarta.

Mengingat banyaknya sekolah yang perlu diteliti, sementara peneliti memiliki keterbatasan tenaga dan waktu, maka peneliti memilih 3 sekolah sebagai representasi kesebelas sekolah itu. Masing-masing sekolah memiliki keunggulan dan prestasi yang berbeda-beda, oleh karena itu peneliti menentukan pengelompokkan sekolah berdasarkan hasil prestasi akademik, khususnya hasil nilai ujian nasional. Dari kesebelas sekolah, dapat dikelompokkan menjadi 3 kelompok yaitu kelompok pertama adalah sekolah-sekolah yang hasil nilai ujian nasionalnya tinggi, kelompok kedua sekolah-sekolah yang hasil nilai ujian nasionalnya di bawah rata-rata dari kelompok pertama, sedangkan kelompok ketiga adalah sekolah-sekolah yang rata-rata hasil nilai ujiannya rendah.

Berdasarkan data yang peneliti peroleh dan penentuan dengan undian untuk masing-masing kelompok, maka terpilih 3 sekolah, yaitu (1) SMA 5 yang mewakili kelompok rangking atas, (2) SMA 7 yang mewakili kelompok rangking menengah, dan (3) SMA 4 Yogyakarta yang mewakili kelompok rangking bawah.

Populasi penelitian ini adalah guru dari tiap-tiap unit analisis sekolah yang mewakili kelompok masing-masing rangking sekolah, yaitu ketiga sekolah terpilih.
Mengingat tidak memungkinkan meneliti semua guru dari ketiga sekolah yang terpilih, peneliti mengambil sampel dari populasi guru yang ada di ketiga sekolah tersebut. Untuk menentukan jumlah sampel dari populasi di atas, peneliti menggunakan tabel yang dikembangkan oleh Isaac dan Michael (Sugiyono, 2006, pp.126-128) untuk dipergunakan penghitungan sampel proporsional sebagaimana cara penghitungan yang dicontohkan Sugiyono (2006, p.130), dengan taraf kesalahan $5 \%$, hasilnya sebagai berikut: 35 orang guru dari SMA 5, 33 guru dari SMA 7, dan 37 guru dari SMA 4.

\section{Prosedur}

Penelitian ini bertujuan untuk menguji hipotesis atau menjawab permasalahan penelitian yaitu ada tidaknya pengaruh kepemimpinan kepala sekolah, motivasi kerja, dan budaya organisasi terhadap kompetensi guru, baik masing-masing variabel indepenpent maupun keseluruhan variabel independen terhadap variabel dependent, yaitu kompetensi guru (Y).

\section{Definisi Operasional Variabel}

Kepemimpinan Kepala Sekolah (X1) Kepala sekolah merupakan motor penggerak, penentu arah kebijakan sekolah, yang akan menentukan bagaimana tujuantujuan sekolah dan pendidikan pada umumnya di realisasikan (Mulyasa, 2009, p.42). Dengan kepemimpinan kepala sekolah yang efektif diharapkan kepala sekolah mampu meningkatkan kompetensi guru. Selanjutnya Mulyasa (2009, p.98) menyebutkan bahwa seorang kepala sekolah harus melakukan perannya sebagai pimpinan dengan menjalankan fungsi sebagai edukator (pendidik), manajer, administrator, supervisor, leader (pemimpin), inovator, motivator.

Kepala sekolah yang mampu menjalankan fungsi-fungsi kepemimpinan di atas akan dapat meningkatkan kompetensi guru.

Motivasi Kerja (X2). Herzberg dan kawan-kawan merumuskan teori motivasi yang disebut dengan Teori Dua Faktor 
(Davis, 1981, pp.65-69). Dua faktor tersebut adalah: (1) faktor "Motivasional", dan (2) faktor "Hygiene". Faktor motivasional adalah hal-hal yang mendorong berprestasi yang sifatnya instrinsik yang berarti bersumber dalam diri seseorang, sementara yang dimaksud dengan faktor hygiene atau pemeliharaan adalah faktor-faktor yang sifatny ekstrinsik yang berarti bersumber dari luar diri yang turut menentukan perilaku seseorang dalam bekerja. Faktor motivasional meliputi: prestasi yang dicapai, pengakuan, dunia kerja, tanggung jawab dan kemajuan. Yang termasuk faktor pemeliharaan yang bersifat ekstrinsik adalah hubungan interpersonal antara atasan dan bawahan, teknik supervisi, kebijakan administratif, kondisi kerja, dan kehidupan pribadi. Kedua faktor tersebut berpengaruh besar terhadap motivasi seseorang dalam meningkatkan kompetensi profesionalismenya.

Dapat disimpulkan bahwa kedua faktor ini berpengaruh terhadap motivasi kerja seseorang, atau berkaitan dengan fokus penelitian ini berpengaruh terhadap kompetensi guru.

Budaya Organisasi (X3). Budaya organisasi, atau dikenal juga budaya kerja, merupakan seperangkat karakterisitik yang membentuk nilai-nilai organisasi, yang oleh Robbins disusun 7 karakteristik budaya organisasi, yaitu: (1) innovation and risk taking (inovasi dan pengambilan resiko); (2) attention to detail (perhatian ke rincian); (3) orientasi manfaat; (4) orientasi orang; (5) orientasi tim; (6) keagresifan; (7) stabilitas (Kemantapan) (Robbins, 1996, p.289).

Budaya organisasi sangat berperan dalam mengarahkan perilaku anggotanya sehingga para anggotanya akan melakukan pekerjaan sesuai dengan tugas dan tanggungjawabnya.

Budaya organisasi yang dikembangkan oleh masyarakat di sekolah akan mempengaruhi pekerja terutama dalam upaya meningkatkan kompetensi profesionalisme guru di sekolah itu.

Kompetensi Guru (Y). Kompetensi guru merupakan kemampuan seseorang guru dalam melaksanakan kewajiban-kewajiban secara bertanggung jawab dan la- yak (Usman, 2004, p.14). Dapat disimpulkan bahwa kompetensi merupakan kemampuan dan kewenangan guru dalam melaksanakan profesinya.

Kompetensi guru merupakan hasil upaya guru dalam meningkatkan kemampuan profesinya yang menurut UU RI Nomor 14, pasal 10 kompetensi guru meliputi: (1) kompetensi pedagogik, (2) kompetensi kepribadian, (3) kompetensi sosial, dan (4) kompetensi professional.

Kompetensi Guru (Y) dipengaruhi oleh faktor Kepemimpinan Kepala Sekolah (X1), Motivasi Kerja (X2), dan Budaya Organisasi (X3). Upaya yang dapat dilakukan dalam meraih kompetensi profesional guru adalah melalui optimalisasi peran kepala sekolah. Kepala sekolah sebagai pengelola pendidikan di sekolahnya memiliki tugas mengembangkan kompetensi gurunya, tentu tidak hanya yang berkaitan dengan penguasaan materi, tetapi seluruh kompetensi yang semestinya dimiliki.

Selain kepala sekolah, hal yang dapat mendorong kompetensi guru adalah motivasi kerja guru itu sendiri. Motivasi kerja dapat mendorong peningkatan kompetensi guru. Semangat atau motivasi guru dalam meraih kompetensi ideal yang dipersyaratkan dalam Undang-Undang Guru tahun 2005, berupa kompetensi pedagogik, kompetensi kepribadian, kompetensi sosial, dan kompetensi profesional.

Selain motivasi kerja guru, budaya organisasi dapat pula menumbuhkan peningkatan kompetensi guru. Budaya organisasi adalah cara pandang yang menumbuhkan keyakinan atas dasar nilai-nilai yang diyakini guru untuk mewujudkan kompetensi profesionalnya, sehingga budaya organisasi turut mempengaruhi peningkatan kompetensi guru.

\section{Data, Intrumen dan Teknik Pengumpulan Data}

Pada penelitian ini pengambilan data dilakukan dengan satu cara, yaitu angket. Angket yang berfungsi menggali informasi terkait dengan penelitian yang akan dilakukan ini ditujukan kepada guru. 
Angket ini berupa pertanyaan ataupun pernyataan kepada responden yang jawabannya telah tersedia, sehingga responden tinggal memilih jawaban yang sesuai dengan persepsi yang mereka miliki atas pertanyaan ataupun pernyataan yang diajukan. Di dalam angket terdapat beberapa pernyataan yang disusun berdasarkan indikator-indikator dari landasan teori yang ada sehingga dapat mengukur variabel yang hendak diteliti.

Instrumen penelitian mempunyai peranan yang sangat penting dalam penelitian terutama penelitian kuantitatif karena kualitas hasil penelitian sangat dipengaruhi oleh kualitas instrumen. Pengembangan kisi-kisi instrumen dalam penelitian ini dibuat berdasarkan dari hasil kajian teori dari bab sebelumnya.

Kompetensi Guru (Y); meliputi kompetensi pedagogik, kepribadian, sosial, profesional (UU Guru dan Dosen, No 14 th 2005 ps 10, ayat 1). Pedagogik: memahami peserta didik secara mendalam (2 butir), mampu merencanakan pembelajaran (2), mampu melaksanakan pembelajaran (4), mampu melakukan penilaian hasil belajar (2), mengembangkan siswa untuk mengaktualisasikan berbagai potensi yang dimilikinya (2). Kepribadian: memiliki kepribadian yang mantap dan stabil (2 butir). Memiliki kepribadian yang dewasa (2), memiliki kepribadian yang arif (3), memiliki kepribadian yang berwibawa (3), berakhlak mulia dan dapat menjadi tauladan bagi siswa (2). Sosial: mampu berkomunikasi dan bergaul secara efektif dengan siswa (2 butir), mampu berkomunikasi dan bergaul secara efektif dengan sesama pendidik dan tenaga kependidikan (2), mampu berkomunikasi dan bergaul secara efektif dengan orangtua/wali siswa dan masyarakat sekitar (2). Profesional: menguasai substansi keilmuan yang terkait dengan mata pelajaran (2), menguasai struktur dan metode keilmuan (2), menguasai isu-isu mutakhir (2).

Kepemimpinan Kepala Sekolah (X1); sebagai educator, manager, administrator, supervisor, leader, inovator, motivator (Mulyasa, 2009, p.90). Sebagai educator: mampu meningkatkan profesionalisme guru (2 butir), mampu memotivasi guru dan siswa untuk disiplin (2), mampu membina kepribadian guru (2). Sebagai manager: mampu merencanakan dan melaksanakan program pendidikan sekolah (2), mampu merencanakan, dan melaksanakan program pengembangan fasilitas sekolah (2), mampu merencakan dan melak-sanakan program pengembangan guru di sekolah (2). Sebagai administrator: mampu melaksanakan administrasi kurikulum (2), mampu melaksanakan administrasi keuangan (2), mampu melaksanakan administrasi kepegawaian (2), mampu melaksanakan administrasi fasilitas sekolah (2). Sebagai supervisor: mampu melaksanakan supervisi klinis terhadap guru dengan metode diskusi, kunjungan kelas maupun pembicaraan individual (2), mampu melakukan supervisi dengan memberikan motivasi guru agar kreatif dan produktif (2). Sebagai leader: memberikan keteladanan kepada guru (2), memiliki keahlian dalam memimpin sekolah (2). Sebagai inovator: mampu bekerja secara kreatif dan integratif (2), mampu bekerja secara rasional, objektif, fleksibel, dan adaptabel (2). Sebagai motivator: mampu memotivasi guru dalam bekerja melalui pengaturan lingkungan fisik kelas dan sekolah (2), menciptakan suasana kerja yang kondusif (2), mampu memotivasi guru dalam bekerja melalui penyediaan sumber belajar (2).

Motivasi Kerja (X2); Faktor motivasional' bersifat intrinsik, sedang faktor 'pemeliharaan (hygiene)' bersifat ekstrinsik. Kedua faktor ini berpengaruh terhadap motivasi kerja seseorang (Teori dua faktor Herzberg dalam Davis, 1981, pp.65-69). Faktor motivasional: adanya kesempatan berprestasi (2 butir), pengakuan dari teman sejawat (2), merasa bangga dengan pekerjaannya sebagai guru (2), bertanggung jawab atas pekerjaannya (2), pekerjaan itu sendiri (2), kesempatan untuk meningkatkan karier (2). Faktor pemeliharaan: gaji atau honor yang diterima (2), kondisi kerja yang menyenangkan (2), kebijakan pimpinan sekolah (2), hubungan antar pribadi (2). 
Budaya Organisasi (X3): 7 karakteristik budaya organisasi yang berperan dalam mengarahkan perilaku anggotanya untuk melakukan pekerjaan sesuai tugas dan tanggung jawabnya yang mengarah pada peningkatan kompetensi sesuai kemauan organisasi (Robbins, 1996, p.289). Inovasi dan pengambilan resiko: tumbuhnya inisiatif, kreatifitas, dan tidak takut resiko demi tujuan organisasi (3), perhatian ke rincian: kebiasaan melakukan pekerjaan dengan teliti dan akurat (2), orientasi hasil: berusaha memenuhi target yang diinginkan organisasi (2), orientasi orang: mengerjakan pekerjaan dengan penuh penghayatan (2), orientasi tim: terciptanya kekompakkan kerja (2), keagresifan: suasana yang mendorong segera terselesaikannya pekerjaan untuk dapat mengerjakan pekerjaan lain (2), kemantapan: terciptanya kenyamanan dan stabilitas kerja yang baik (3).

Teknik pengumpulan data adalah dengan menyebarkan angket untuk diisi oleh responden yang telah ditentukan jumlah dan targetnya. Pengukuran nilai persepsi responden dengan numerical rating scale dihitung dari 1 sampai dengan 5 untuk tiap butir tanggapan atas pertanyaan atau pernyataan. Hasil isian angket dianalisis dengan teknik statistik dan hasilnya diambil kesimpulan.

Hasil uji instrumen kepemimpinan kepala sekolah dari 38 butir soal non-tes menunjukkan semua valid dan reliabel, instrumen motivasi kerja 20 butir soal nontes valid dan reliabel, budaya organisasi 16 butir soal non-tes valid dan reliabel, sedangkan instrumen kompetensi guru 36 butir soal non-tes semua valid dan reliabel, kecuali satu soal nomor 33 yang tidak valid sehingga tidak digunakan.

\section{Teknik Analisis Data}

Mengingat hasil penelitian ini dapat diberlakukan untuk populasi dimana sampel penelitian diambil, maka teknis analisis yang digunakan adalah statistik inferensial (Sugiyono, 2006, p.208). Statistik inferensial sering pula disebut statistik induktif atau statistik probabilitas. Teknik ini digunakan untuk menganalisis data sampel dan hasilnya diberlakukan untuk populasi.

Agar data dapat dianalisis dengan menggunakan regresi linier ganda maka perlu dilakukan beberapa uji persyaratan, diantaranya adalah: (1) jenis skala data penelitian, (2) uji normalitas, (3) uji kelinieran, (Sudarmanto, 2005, p.102). Hasilnya menunjukkan semua variabel penelitian telah memenuhi persyaratan untuk dilakukan analisis regresi ganda dalam rangka menjawab pertanyaan penelitian.

Tabel 1. Uji Normalitas Data:

\begin{tabular}{ccccc}
\hline Variabel & $\begin{array}{c}\text { Asymp. Sig. } \\
\text { (2-tailed) }\end{array}$ & $\begin{array}{c}\text { Tingkat } \\
\text { Alpha }\end{array}$ & Kondisi & Kesimpulan \\
\hline X1 & 0,060 & 0,05 & S > A & Normal \\
X2 & 0,070 & 0,05 & S > A & Normal \\
X3 & 0,438 & 0,05 & S > A & Normal \\
Y & 0,640 & 0,05 & S > A & Normal \\
\hline
\end{tabular}

Tabel 2. Hasil Linearitas

\begin{tabular}{ccccc}
\hline Keterangan & Signifikansi & Alpha & Kondisi & Simpulan \\
\hline$Y^{*} \mathrm{X} 1$ & 0,232 & 0,05 & S > A & Linear \\
$Y^{*}$ X2 & 0,572 & 0,05 & S > A & Linear \\
$Y^{*}$ X3 & 0,459 & 0,05 & S > A & Linear \\
\hline
\end{tabular}

\section{Hasil Penelitian dan Pembahasan}

Uji hipotesis secara simultan yaitu untuk menguji pengaruh secara bersamasama variabel bebas terhadap variabel terikat digunakan uji F. Dari hasil perhitungan didapatkan nilai $\mathrm{F}$ hitung sebesar 4,448 (signifikansi $\mathrm{F}=0,006$ ). Jadi $\mathrm{F}$ hitung $>\mathrm{F}$ tabel $(4,448>2,694)$ atau Sig $F<5 \%$ $(0,006<0,05)$.

Hasil perhitungan menunjukkan bahwa F hitung lebih besar dari F tabel; pada taraf signifikansi 0,006 $<0,05$ yang berarti signifikan dan positif (Santoso, 2002, p.151). Sehingga dapat disimpulkan bahwa pengaruh (1) kepemimpinan kepala sekolah, (2) motivasi kerja, dan (3) budaya organisasi secara bersama-sama berpengaruh secara signifikan dan positif terhadap kompetensi guru. Dapat pula dinyatakan bahwa terdapat pengaruh yang signifikan dan positif dari variabel bebas $X_{1}, X_{2}$, dan $\mathrm{X}_{3}$ terhadap variabel terikat $\mathrm{Y}$. 
Hasil tersebut menunjukkan Ho ditolak, dan Ha diterima. Dengan demikian hipotesis Ha diterima, yaitu sebagai berikut.

Terdapat pengaruh positif dan signifikan variabel $X_{1}$ (Kepemimpinan Kepala Sekolah), variabel $X_{2}$ (Motivasi Kerja), dan variabel $X_{3}$ (Budaya Organisasi) secara bersama-sama atau simultan terhadap $Y$ (Kompetensi Guru) SMA Negeri kota Yogyakarta.

Besarnya sumbangan variabel independen terhadap variabel dependen (kompetensi guru) adalah dengan melihat besarnya nilai koefisien $\mathrm{R}$ (koefisien regresi linear ganda) yaitu 0,342; kuadrat dari nilai ini adalah 0,117 (R Square), sehingga dapat disimpulkan besarnya sumbangan variabel independen (X1, X2, dan X3) adalah 11,7 \%; Dengan demikian pengujian hipotesis yang pertama (Mayor) sudah selesai/terjawab.

Pengujian Hipotesis Minor Nomor 1, yaitu: $H o$ : Tidak terdapat pengaruh positif dan signifikan variabel $\mathrm{X}_{1}$ (Kepemimpinan Kepala Sekolah) terhadap variabel $Y$ (Kompetensi Guru) SMA Negeri di kota Yogyakarta. Ha: Terdapat pengaruh positif dan signifikan variabel $X_{1}$ (Kepemimpinan Kepala Sekolah) terhadap variabel $Y$ (Kompetensi Guru) SMA Negeri di kota Yogyakarta.

Dengan kriteria keputusan: Terima Ho dan tolak Ha apabila nilai $\mathrm{t}$ hitung $<\mathrm{t}$ tabel, dan nilai Sig. $t>0,05$. Tolak Ho dan terima Ha apabila nilai $\mathrm{t}$ hitung $>\mathrm{t}$ tabel, dan nilai Sig. $t<0,05$. Untuk menguji hipotesis, maka digunakan penghitungan dengan uji t. Data yang diperoleh sebagai dasar adalah hasil output penghitungan dengan SPSS 17, sebagai berikut: Dari output dengan perhitungan SPSS 17 dapat dijelaskan sebagai berikut:

Uji t variabel $X_{1}$ (Kepemimpinan Kepala Sekolah) didapatkan $t$ hitung sebesar 1,841 dengan signifikansi t sebesar 0,069. Karena $\mathrm{t}$ hitung lebih kecil dari $\mathrm{t}$ tabel $(-1,841<1,659)$ dan signifikansi t lebih besar dari $5 \% \quad(0,069>0,05)$, maka secara parsial variabel $X_{1}$ (Kepemimpinan Kepala Sekolah) tidak berpengaruh secara positif dan signifikan terhadap variabel Y (Kom- petensi Guru). Hasil penghitungan ini menunjukkan bahwa hipotesis Minor 1; Ho diterima dan Ha ditolak, sehingga disimpulkan bahwa:

Secara parsial, tidak terdapat pengaruh positif dan signifikan variabel $\mathrm{X}_{1}$ (Kepemimpinan Kepala Sekolah) terhadap variabel Y (Kompetensi Guru) SMA Negeri di kota Yogyakarta.

Pengujian Hipotesis Minor Nomor 2, yaitu: Hasil uji $\mathrm{t}$ variabel $\mathrm{X}_{2}$ (Motivasi Kerja) didapatkan $t$ hitung sebesar 1,352 dengan signifikansi t sebesar 0,179. Karena $\mathrm{t}$ hitung lebih kecil dari $\mathrm{t}$ tabel $(1,352<$ $1,659)$ dan signifikansi t lebih besar dari $5 \%$ $(0,179>0,05)$, maka secara parsial variabel $\mathrm{X}_{2}$ (Motivasi Kerja) tidak berpengaruh secara positif dan signifikan terhadap variabel Y (Kompetensi Guru). Hasil penghitungan ini menunjukkan bahwa hipotesis Minor Nomor 2; Ho diterima dan $\mathrm{Ha}$ ditolak, sehingga disimpulkan bahwa:

Secara parsial, tidak terdapat pengaruh positif dan signifikan variabel $\mathrm{X}_{2}$ (Motivasi Kerja) terhadap variabel Y (Kompetensi Guru) SMA Negeri di kota Yogyakarta.

Pengujian Hipotesis Minor Nomor 3, yaitu: Hasil uji t variabel $\mathrm{X}_{3}$ (Budaya Organisasi) didapatkan $t$ hitung sebesar 2,607 dengan signifikansi $t$ sebesar 0,011 . Karena t hitung lebih besar dari t tabel $(2,607>$ $1,659)$ dan signifikansi $t$ lebih kecil dari $5 \%$ $(0,011<0,05)$, maka secara parsial variabel $\mathrm{X}_{3}$ (Budaya Organisasi) berpengaruh secara positif dan signifikan terhadap variabel $Y$ (Kompetensi Guru). Hasil penghitungan ini menunjukkan bahwa hipotesis Minor Nomor 3; Ho ditolak dan Ha diterima, sehingga disimpulkan bahwa:

Secara parsial, terdapat pengaruh positif dan signifikan variabel $X_{3}$ (Budaya Organisasi) terhadap variabel $Y$ (Kompetensi Guru) SMA Negeri kota Yogyakarta.

\section{Pembahasan}

Koefisien Determinasi; Koefisien determinasi $R^{2}$ ( $R$ Square) adalah sebesar 0,117 . Nilai tersebut dapat digunakan sebagai ukuran untuk menyatakan kecocokkan garis regresi yang diperoleh. Semakin besar nilai koefisien determinasi, maka 
semakin kuat pula kemampuan model regresi tersebut dalam menjelaskan variasi yang terjadi pada variabel terikat Y. Hasil analisis secara rinci disajikan dalam model Summary.

Tabel 3. Model Summary

\begin{tabular}{llrrrr}
\multicolumn{4}{c}{ Model Summary } \\
\hline Model & R & R Square & R Square & the Estimate \\
\hline 1 & $.342^{\mathrm{a}}$ & .117 & .090 & 11.92619 \\
\hline
\end{tabular}

a. Predictors: (Constant), X3, X1, X2

Hasil tersebut memberikan gambaran bahwa kemampuan variabel bebas $X_{1}, X_{2}$, dan $X_{3}$ untuk menjelaskan variasi yang terjadi pada variabel terikat $\mathrm{Y}$ sebesar 0,117 ; atau $11,7 \%$; selebihnya dipengaruhi oleh faktor lain yang tidak dapat dijelaskan. Dengan kata lain, fenomena kompetensi guru hanya mampu dijelaskan secara bersama-sama oleh adanya pengaruh kepemimpinan kepala sekolah, motivasi kerja, dan budaya organisasi sebesar $11,7 \%$, sedangkan selebihnya dijelaskan oleh faktor lain, yang tidak dapat dijelaskan dalam model regresi yang diperoleh.

Hasil analisis regresi sederhana yang yang terangkum dalam output SPSS 17, menunjukkan bahwa koefisien determinasinya berturut-turut adalah 0,$003 ; 0,033$; 0,87 . Hal ini berarti bahwa secara parsial kemampuan variabel kepemimpinan kepala sekolah $\left(X_{1}\right)$ untuk menjelaskan variasi yang terjadi terhadap kompetensi guru adalah sebesar $0,3 \%$. Variabel motivasi kerja $\left(X_{2}\right)$ untuk menjelaskan variasi yang terjadi terhadap kompetensi guru adalah sebesar 3,3\%, sedangkan variabel budaya organisasi $\left(X_{3}\right)$ mampu menjelaskan variasi yang terjadi terhadap kompetensi guru adalah sebesar $87 \%$.

Uraian tersebut menjelaskan bahwa secara bersama-sama faktor kepemimpinan kepala sekolah, motivasi kerja, dan budaya organisasi memiliki pengaruh terhadap kompetensi guru, namun demikian secara sendiri-sendiri hanya budaya organisasi yang memiliki pengaruh terhadap kompetensi guru. Persamaan Garis Regresi.

Rangkuman koefisien regresi linear ganda disajikan pada tabel 15 .

Tabel 4. Rangkuman Koefisien Linear Ganda

\begin{tabular}{ccc}
\hline No & Variabel Bebas & Koefisien Regresi \\
\hline & Konstanta & 105,433 \\
1 & X1 & 0,147 \\
2 & X2 & 0,295 \\
3 & X3 & 0,655 \\
\hline
\end{tabular}

Koefisien regresi linear ganda berturut-turut adalah: 105,433; - 0,147; 0,295; 0,655 yang masing-masing merupakan konstanta, koefisien dari variabel $X_{1}$, koefisien dari variabel $X_{2}$, dan koefisien dari variabel $X_{3}$. Dengan demikian persamaan garis regresi linear gandanya dapat dinyatakan sebagai: $\hat{Y}=105,433-0,147 X_{1}$ $+0,295 X_{2}+0,655 X_{3}$

Berdasarkan persamaan garis regresi yang diperoleh, maka perubahan kompetensi guru terjadi searah dengan tingkat perubahan yang terjadi pada kepemimpinan kepala sekolah, motivasi kerja dan budaya organisasi. Dikatakan searah karena koefisien regresi yang ada semuanya bertanda positif, kecuali koefisien $\mathrm{X}_{1}$. Oleh karena itu secara bersama-sama bertambahnya pengaruh kepemimpinan kepala sekolah, bertambahnya pengaruh motivasi kerja, dan budaya organisasi, akan mengakibatkan bertambahnya pengaruh pada kompetensi guru.

Selain penjelasan di atas, persamaan regresi tersebut dapat diinterpretasikan sebagai berikut:

Harga konstanta regresi 105,433 . Ini berarti bahwa apabila nilai $X_{1}, X_{2}$, dan $X_{3}$, sama dengan nol, maka tingkat variabel $Y$ sebesar 105,433 poin. Dengan kata lain jika tidak ada pengaruh dari kepemimpinan kepala sekolah, motivasi kerja, dan budaya organisasi, maka nilai kompetensi guru akan sebesar 105,433.

Harga koefisien $\beta_{1}=-0,147$. Ini berarti bahwa apabila pengaruh nilai dari variabel $X_{1}$ mengalami kenaikan sebesar satu poin, maka tingkat variabel $\mathrm{Y}$ akan 
meningkat sebesar - 0,147 atau akan berkurang sebesar 0,147.

Harga koefisien $\beta_{2}=0,295$. Ini berarti bahwa apabila pengaruh nilai dari variabel $\mathrm{X}_{2}$ mengalami kenaikan sebesar satu poin, maka tingkat variabel $\mathrm{Y}$ akan meningkat sebesar 0,295. Atau jika pengaruh motivasi kerja bertambah sebesar satu poin, maka kompetensi guru akan meningkat sebesar 0,295 .

Harga koefisien $\beta_{3}=0,655$. Ini berarti bahwa apabila pengaruh nilai $X_{3}$ mengalami kenaikan sebesar satu poin, maka tingkat variabel $\mathrm{Y}$ akan meningkat sebesar 0,655 . Atau jika pengaruh budaya organisasi bertambah sebesar satu poin, maka kompetensi guru akan meningkat sebesar 0,655 .

\section{Simpulan dan Saran}

Simpulan

Hasil penelitian dengan analisis regresi ganda dengan uji $\mathrm{F}$ menunjukkan bahwa secara simultan ada pengaruh yang positif dan signifikan antara kompetensi guru sebagai variabel terikat $(\mathrm{Y})$, dengan kepemimpinan kepala sekolah $\left(X_{1}\right)$, motivasi kerja $\left(X_{2}\right)$, serta budaya organisasi $\left(X_{3}\right)$ yang masing-masing merupakan variabel bebas.

Ini berarti bahwa kepemimpinan kepala sekolah, motivasi kerja, dan budaya organisasi secara bersama-sama berpengaruh positif dan signifikan terhadap kompetensi guru. Sebaliknya secara bersama-sama, semakin kurang baiknya kepemimpinan kepala sekolah, motivasi kerja, dan budaya organisasi akan mengakibatkan semakin rendah pula kompetensi guru.

Walaupun demikian hasil analisis di atas sedikit berbeda dengan hasil uji $t$ untuk pembuktian hipotesis minor yang menunjukkan bahwa: (1) secara parsial, tidak terdapat pengaruh positif dan signifikan variabel $X_{1}$ (Kepemimpinan Kepala Sekolah) terhadap variabel $Y$ (Kompetensi Guru) SMA Negeri kota Yogyakarta, (2) demikian pula secara parsial, tidak terdapat pengaruh positif dan signifikan variabel $\mathrm{X}_{2}$ (Motivasi Kerja) terhadap variabel $\mathrm{Y}$ (Kompetensi Guru), (3) namun demikian secara parsial terdapat pengaruh positif dan signifikan variabel $X_{3}$ (Budaya Organisasi) terhadap variabel $Y$ (Kompetensi Guru) SMA Negeri kota Yogyakarta.

Berdasarkan hasil penelitian dan pembahasan, selanjutnya dapat diambil kesimpulan bahwa menurut persepsi guru yang menjadi sampel penelitian pada sekolah-sekolah yang dijadikan sampel penelitian, menunjukkan bahwa secara bersama-sama faktor kepemimpinan kepala sekolah, motivasi kerja, dan budaya organisasi di sekolah berpengaruh positif dan signifikan terhadap kompetensi guru, namun berdasarkan hasil uji $t$ menunjukkan bahwa secara sendiri-sendiri faktor kepemimpinan kepala sekolah dan motivasi kerja tidak berpengaruh secara positif dan signifikan terhadap kompetensi guru, sementara itu budaya organisasi memiliki pengaruh positif dan signifikan terhadap kompetensi guru.

Dari hasil analisis regresi ganda diperoleh koefisien ganda 0,342. Dilihat dari kemampuan dalam menjelaskan variasi dan perubahan yang terjadi pada variabel kompetensi guru, maka ketiga variabel bebas tersebut mampu menjelaskan sebesar 11,7 persen $\left(R^{2}=0,117\right)$. Dengan kata lain, fenomena kompetensi guru hanya mampu dijelaskan secara bersamasama oleh adanya pengaruh kepemimpinan kepala sekolah, motivasi kerja, dan budaya organisasi sebesar $11,7 \%$, sedangkan selebihnya dijelaskan oleh faktor lain, yang tidak dapat dijelaskan dalam model regresi yang diperoleh.

Kesimpulan hasil penelitian tersebut, mempunyai implikasi pada beberapa hal sebagai berikut: (1) mengingat secara bersama-sama kepemimpinan kepala sekolah, motivasi kerja, dan budaya organisasi berpengaruh positif dan signifikan terhadap kompetensi guru, maka upaya-upaya meningkatkan kompetensi guru melalui ketiga aspek tersebut perlu terus dilakukan, (2) kepemimpinan kepala sekolah merupakan faktor penting dalam meningkatkan 
kompetensi guru, oleh karena itu posisi kepala sekolah yang strategis dan memiliki power yang kuat untuk mempengaruhi guru harus dimanfaatkan dengan baik dengan cara-cara yang dapat menumbuhkan semangat para guru untuk meningkatkan kompetensi mereka dengan penuh kesadaran, (3) motivasi kerja dari para guru adalah faktor yang tidak kalah penting. Oleh karena itu semangat kerja para guru perlu terus dipompa baik oleh guru itu sendiri dan juga oleh kepala sekolah, (4) budaya organisasi turut membentuk perilaku guru dalam usaha meningkatkan kompetensi guru. Budaya untuk selalu berusaha meningkatkan kompetensi mereka akan mendorong sikap-sikap guru yang profesional.

Saran

Berdasarkan pada beberapa implikasi, maka penulis memberikan saran: (1) kepala sekolah hendaknya selalu memikirkan upaya peningkatan kompetensi guru, (2) guru dan kepala sekolah harus terus membangun motivasi kerja dengan memberikan pelayanan yang terbaik terhadap para siswanya, salah satu caranya adalah selalu meningkatkan kompetensi guru, (3) kepala sekolah dan guru harus senantiasa menumbuhkan budaya organisasi yang menumbuhkan sikap profesionalisme kerja guru, (4) guru perlu terus menyadari bahwa tugas guru adalah pekerjaan profesi, oleh karena itu guru perlu terus meningkatkan kinerjanya melalui kompetensi yang harus terus dikembangkan, baik kompetensi pedagogik, kompetensi kepribadian, kompetensi sosial, dan kompetensi profesional.

\section{Daftar Pustaka}

Brahmasari, I.A. \& Suprayetno, Agus. (2008). Pengaruh motivasi kerja, kepemimpinan dan budaya organisasi terhadap kepuasan kerja karyawan serta dampaknya pada kinerja perusahaan (studi kasus pada pt. pei hai international wiratama Indonesia). Jurnal Manajemen dan Kewira- usahaan, Vol.10, no. 2, September 2008: 124-135.

Darling, Linda., Hammon \& others. (2006). Powerful teacher education. USA: Jossey_Bass-A Wiley Imprint.

Ditjen PMPTK. (2008). Penilaian kinerja guru. Jakarta: Departemen Pendidikan Nasional

Depdiknas. Undang-undang nomor 14 tahun 2005 tentang guru dan dosen

Depdiknas. Peraturan menteri pendidikan nasional republik indonesia nomor 16 tahun 2007 tentang standar kualifikasi akademik dan kompetensi guru.

Farlen, Frans. (2011). Tesis: Pengaruh motivasi kerja dan kemampuan kerja terhadap kinerja karyawan (studi pada karyawan pt. united tractors, tbk samarinda). Yogyakarta: Jurusan Administrasi Bisnis, Fakultas Ilmu Sosial dan Ilmu Politik, Universitas Pembangunan Nasional "Veteran"

Hendri, Edy. Guru berkualitas: profesional dan cerdas emosi. Jurnal Saung Guru: Vol. 1, Nomor 2, tahun 2010

Hersey, Paul \& Blanchard, Ken. (1982). Management of organizational behavior. New Jersey: Prentice Hall.

Mania, Siti. (2011). Profesionalitas kepala sekolah: analisis antara idealita dan realita. Lentera Pendidikan, Vol. 14, No 1, Juni 2011.

Mulyasa. (2009). Kepala sekolah profesional. Bandung : PT Remaja Rosdakarya

Kedaulatan Rakyat, Harian Yogyakarta. Calon siswa bisa kombinasikan pilihan. Selasa, 19 Juni 2012. Halaman 2

Kedaulatan Rakyat, Harian Yogyakarta. Calon siswa KMS disarankan ke SMK. Rabu, 20 Juni 2012, halaman 2.

Kompas tanggal 1 November 2010. Kualitas guru lolos sertifikasi tetap rendah. http://edukasi.kompas.com/read/ 2010/11/01/06080956/Kualitas.Gu $\underline{\text { ru.Lolos.ertifikasi.Tetap.Rendah }}$ 
diakses tanggal 8 agustus 2013 jam 11:58

Kurniah, Tri. (2011). Peran guru dalam administrasi sekolah. Selasa, 10 Mei 011.(http://ilmuprofesikependidikan.blogspot.com/2011/05/peran-gurudalam-administrasi-seko-lah.html diunduh 17-08-2013, jam 06.15 )

Preedy, Margaret. (1993). Managing the effective school. London: PCP.

Radar Lampung, Harian. Kamis - 22 November 2012. Menjadi Guru di Era Perubahan. $\underline{\text { http://dwi- }}$ rohmadi.blogspot.com/2012/12/m enjadi-guru-di-era-perubahan.-html 12-08-2013 jam 11.33

Robbins, S.P. (1996). Perilaku organisasi. PT Prenhallindo. Jakarta. Edisi Bahasa Indonesia.

Santoso, Singgih. (2002). Spss statistik multifariat. Jakarta: PT Elex Media Komputindo.
Sudarmanto, R.G. (2005). Analisis regresi linear ganda dengan SPSS. Yogyakarta: Graha Ilmu.

Sugiyono. (2006). Metode penelitian pendidikan. Bandung: Alfabeta

Suyanto \& Hisyam, Djihad. (2000). Refleksi dan reformasi pendidikan di indonesia memasuki milenium III. Yogyakarta: Adi Cita Karya Nusa.

Sallis, Edward. (2008). Total quality management in education. IRCiSoD

Soetjipto \& Kosasi, Raflis. (1999). Profesi keguruan. Jakarta: Depdikbud dan Rineka Cipta.

Usman, M. U. (2004). Menjadi guru profesional. Bandung: PT Remaja Rosdakarya.

Zamroni. (2008). A school based-management volume 1. Yogyakarta: Pascasarjana Universitas Negeri Yogyakarta 